\title{
ALIH FUNGSI LAHAN DAN CURAH HUJAN TERHADAP PERUBAHAN HIDROLOGI SUB DAS SAMIN
}

\author{
Nining Rahayu' ${ }^{1}$, Sutarno'), Komariah ${ }^{3}$ \\ 1)Mahasiswa S1 Program Studi Agroteknologi, Fakultas Pertanian, Universitas Sebelas Maret \\ ${ }^{2}$ )Staf Dosen Program Studi IImu Tanah, Fakultas Pertanian, Universitas Sebelas Maret \\ 3)Staf Dosen Program Studi IImu Tanah, Fakultas Pertanian, Universitas Sebelas Maret \\ Kontak Penulis: Niningrahayu56@student.uns.ac.id
}

\begin{abstract}
Samin sub-watershed is located in the district of Karanganyar and Sukoharjo regency. Every year an increasing number of people in Samin sub-watershed can inflict problems such as the seizure of land use and the amount of available water resources. This study purpose to analyzed the influence of land conversion and rainfall to hydrology conditions Samin sub-watershed in 2005-2015. This research used descriptive exploration method. The study population was the whole unit of land use in the Samin sub-watershed. Data collection techniques used collection of secondary data from BPS Karanganyar-Sukoharjo regency and watering hall. Data were analyzed using correlation analysis of land use and rainfall on hydrology conditions Samin sub-watershed. The results showed that the wetland and forest land decreased by an average of $44,76 \mathrm{ha}^{-1}$ year and 102,5 ha ${ }^{-1}$ year. Residential land, fields and plantations increased by an average of $26,8 \mathrm{ha}^{-1}$ year, $54,07 \mathrm{ha}^{-1}$ year and $26,82 \mathrm{ha}^{-1}$ year. In period 2005-2010 and 2011-2015, Samin sub-watershed has declined average on annual charge $\left(-3.117,42 \mathrm{~m}^{3} / \mathrm{second}\right)$, value of coefficient run-off $(-0,11)$, sedimentation $(-0,01 \mathrm{~mm})$ and increase average on value of coefficient of river regime $(+91,02)$ and $\mathrm{CV}_{\text {charge }}(+0,35)$. Results of statistical analysis of correlation showed that, decline in wetland, forest and increased fields affect the increase coefficient of river regime. Decreased forest land also increased of fields land and plantations affect the increase of Coefficients of Variants $\left(\mathrm{CV}_{\text {charge }}\right)$. Decreased forest land affects decreased run-off coefficient, sedimentation and annual discharge.
\end{abstract}

Keywords: annual charge, coefficient run-off, land use.

\section{AGROTECHNOLOGY RESEARCH JOURNAL}

Rahayu N, Sutarno, Komariah. 2016. Land conversion and rainfall on samin sub-watershed hydrological condition. Agrotech Res J 1(1): 13-20.

Rahayu N, Sutarno, Komariah. 2016. Alih fungsi lahan dan curah hujan terhadap perubahan kondisi hidrologi sub das samin. Agrotech Res J 1(1): 13-20.

\section{PENDAHULUAN}

Sub DAS Samin merupakan suatu kesatuan wilayah daratan sungai beserta anak-anak sungainya yang terletak di wilayah administrasi berbeda yaitu, bagian hulu terletak di Kabupaten Karanganyar dan bagian hilir terletak di Kabupaten Sukoharjo. Sebagian besar wilayah Sub DAS Samin merupakan kawasan pertanian. Hal tersebut menunjukkan bahwa sebagian besar penduduk di Sub DAS Samin menggantungkan hidupnya terhadap alam. Peningkatan jumlah penduduk membuat Sub DAS Samin menghadapi dua permasalahan yang saling terkait yaitu, perebutan penggunaan lahan dan ketersediaan sumberdaya air.

Penelitian Anna et al. (2010) di daerah Sukoharjo pada periode 1997 dan 2002, menyatakan bahwa, alih fungsi lahan di daerah Sukoharjo berdampak meningkatkan nilai koefisien limpasan (C) dan menurunkan kapasitas resapan air. Penelitian Marganingrum et al. (2013) menunjukkan bahwa, pada DAS Citarum penurunan penggunaan lahan hutan sebesar $27,61 \%$ dan peningkatan lahan terbangun sebesar $25,66 \%$ akan menurunkan debit minimal sebesar $46,39 \%$ dan debit tahunan sebesar $19,44 \%$. Monitoring dan evaluasi tata air di wilayah Sub DAS Samin menjadi diperlukan untuk menghindari penurunan kualitas lingkungan yang akan merugikan masyarakat.
Beberapa penelitian di lokasi Sub DAS Samin telah dilakukan oleh beberapa peneliti antara lain: Sudaryanto (2010) mengenai analisis penggunaan lahan pertanian di kawasan lindung DAS Samin untuk mitigasi bencana longsor dan banjir. Winarno et al. (2008) mengenai kajian bahaya erosi pada lahan kering di Sub DAS Samin. Suyana (2003) mengenai analisis keberlanjutan biofisik lahan pada beberapa tipe agroekosistem di Sub DAS Samin. Penelitian "Alih Fungsi Lahan dan Curah Hujan Terhadap Perubahan Kondisi Hidrologi Sub DAS Samin" ini menjadi diperlukan karena belum adanya penelitian kajian alih fungsi lahan dan curah hujan terhadap kondisi hidrologi di Sub DAS Samin. Penelitian ini bertujuan untuk mengetahui laju alih fungsi lahan di Sub DAS Samin, mengetahui perubahan kondisi hidrologi Sub DAS Samin dan menganalisis pengaruh alih fungsi lahan serta curah hujan terhadap perubahan kondisi hidrologi Sub DAS Samin pada tahun 2005-2015.

\section{METODE PENELITIAN}

Penelitian ini merupakan penelitian deskriptif eksploratif. Informasi alih fungsi lahan di wilayah Sub DAS Samin diambil dari data dari BPS Kabupaten Karanganyar-Sukoharjo, data hidrologi Sub DAS Samin berasal dari Balai Pengairan di Pabelan dan data curah

${ }^{*}$ Fak. Pertanian UNS Surakarta

JI. Ir. Sutami 36 A Surakarta

Alih Fungsi Lahan dan Curah Hujan Terhadap Perubahan Kondisi Hidrologi Sub Das Samin (Nining Rahayu, 13

Sutarno, Komariah) 
hujan berasal dari BPS Kabupaten KaranganyarSukoharjo, Dinas Pekerjaan Umum (DPU) Kabupaten Karanganyar dan Laboratorium Jumantono FP UNS. Karakter fisik Sub DAS Samin dibuat dalam bentuk peta menggunakan program software ArcView GIS. Penelitian ini dilakukan pada bulan Maret - November 2016.Parameter alih fungsi lahan memakai fungsi lahan: pemukiman, sawah, kebun, tegalan dan hutan. Parameter hidrologi Sub DAS memakai parameter: debit tahunan, Koefisien Regim Sungai (KRS), koefisien limpasan $(\mathrm{C})$, coefficient of variants $\left(\mathrm{CV}_{\text {debit }}\right)$ dan sedimentasi. Curah hujan didapat melalui perhitungan berdasarkan metode polygon Thiessen dari titik-titik stasiun pengukur hujan yang berada di wilayah Sub DAS Samin. Data-data tersebut selanjutnya di analisis korelasi menggunakan program software SPSS.

\section{HASIL DAN PEMBAHASAN}

\section{Sub DAS Samin}

Daerah Aliran Sungai (DAS) adalah wilayah daratan yang merupakan satu kesatuan dengan sungai dan anak-anak sungainya, yang berfungsi menampung dan mengalirkan air yang berasal dari curah hujan menuju danau dan laut secara alami, dimana batasan di darat merupakan pemisah topografis dan batasan di laut sampai dengan daerah perairan yang masih terpengaruh aktivitas daratan. Sub DAS merupakan bagian dari DAS yang menerima air hujan dan mengalirkannya melalui anak sungai ke sungai utama. Sub DAS memiliki fungsi utama untuk menyuplai air ke daerah hilir pada suatu wilayah (Departemen Kehutanan 2009).

Pada sistem koordinat UTM, sub DAS Samin terletak di koordinat 49S UTM, 480000-520000 mT dan 9144000-9160000 mU dan memiliki luas sebesar $32.391,8699$ ha. Wilayah administrasi Sub DAS Samin meliputi sembilan Kecamatan di Kabupaten Karanganyar dan lima Kecamatan di Kabupaten Sukoharjo. Sembilan Kecamatan di Kabupaten Karanganyar terdiri dari Kecamatan Tawangmangu, Kecamatan Ngargoyoso, Kecamatan Jumantono, Kecamatan Jaten, Kecamatan Jatiyoso, Kecamatan Jumapolo, Kecamatan Matesih, Kecamatan Karangpandan dan Kecamatan Karanganyar. Lima Kecamatan di Kabupaten Sukoharjo terdiri dari Kecamatan Polokarto, Kecamatan Bendosari, Kecamatan Mojolaban, Kecamatan Grogol dan Kecamatan Sukoharjo.

Sub DAS Samin memiliki bentuk DAS memanjang dan menyempit. Tipe pola aliran sungai yang dimiliki Sub DAS Samin adalah paralel karena anak sungai utama hampir sejajar bermuara pada sungai-sungai utama. Berdasarkan analisis menggunakan ArcView, Sub DAS Samin memiliki panjang keliling 108.28 km, panjang sungai sebesar $410,32 \mathrm{~km}$ dan panjang sungai musiman sebesar $320,77 \mathrm{~km}$. Sungai samin yang berada di lokasi Stasiun Pengamatan Arus Sungai (SPAS) Pos Peren terletak pada orde ke-8 dalam klasifikasi orde sungai menurut metode Strahler. Gambar sungai Sub DAS Samin dapat dilihat pada Gambar 1.

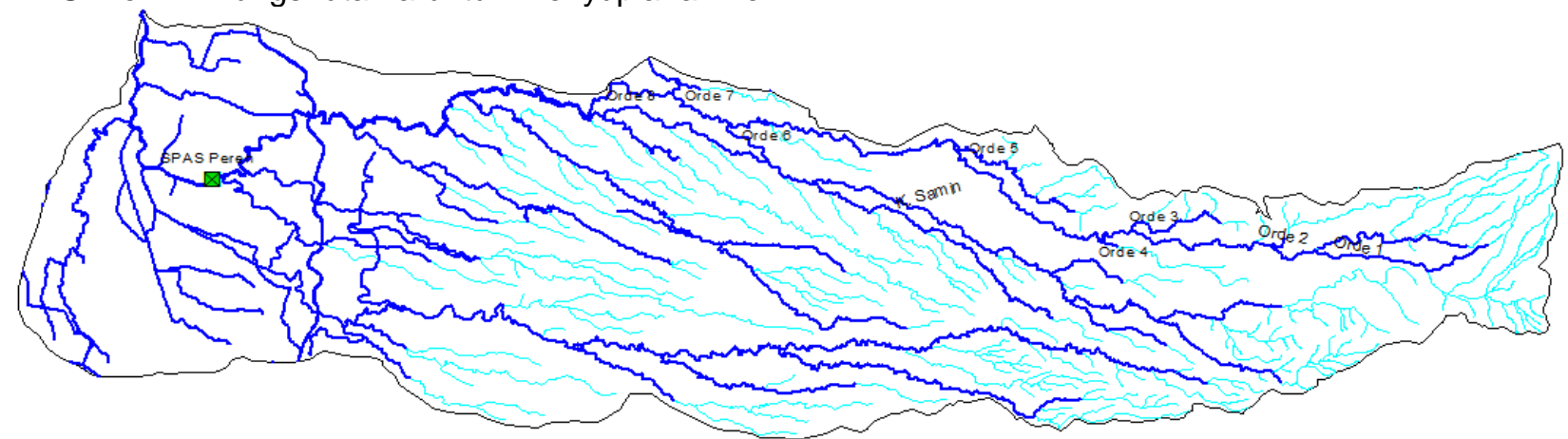

Gambar 1 Kenampakan sungai di Sub DAS Samin menunjukkan sungai Samin termasuk dalam ordo ke-8.

Kerapatan drainase (Dd) adalah panjang sungai yang dimiliki suatu DAS dibagi luasnya. Kerapatan drainase memiliki korelasi dengan laju air larian, jumlah air larian, laju presipitasi, bentuk DAS, dan tipe batuan (Asdak 2007). Kerapatan drainase Sub DAS Samin sebesar $1,28 \mathrm{~km}^{-1} \mathrm{~km}^{2}$. Kerapatan drainase yang tinggi dapat mengurangi debit puncak dan limpasan permukaan akan cepat mengalami infiltrasi (Mardini dan Susanti 2016).

Kondisi hidrologi dapat dipengaruhi oleh iklim, geomorfologi, karakteristik topografi, penggunaan lahan dan jenis tanah (Price 2011 dan Sharma dan Singh
2014). Jenis tanah Sub DAS Samin di bagian hulu terdapat Dystrandepts; Humitropepts; Hydrandepts dan Dystropepts; Tropudults; Tropurthents. Bagian tengah memiliki jenis tanah Dystropepts; Eutropepts; Tropudalfs. Bagian hilir memiliki Eutropepts; Tropaquepts. Peta jenis tanah Sub DAS Samin dapat dilihat pada Gambar 2. Sub DAS Samin memiliki kelerengan yang sangat bervariasi. Bagian hulu Sub DAS Samin memiliki lereng yang sangat curam dan bagian hilir relatif landai. Kelas lereng Sub DAS Samin dapat dilihat pada Gambar 3. 


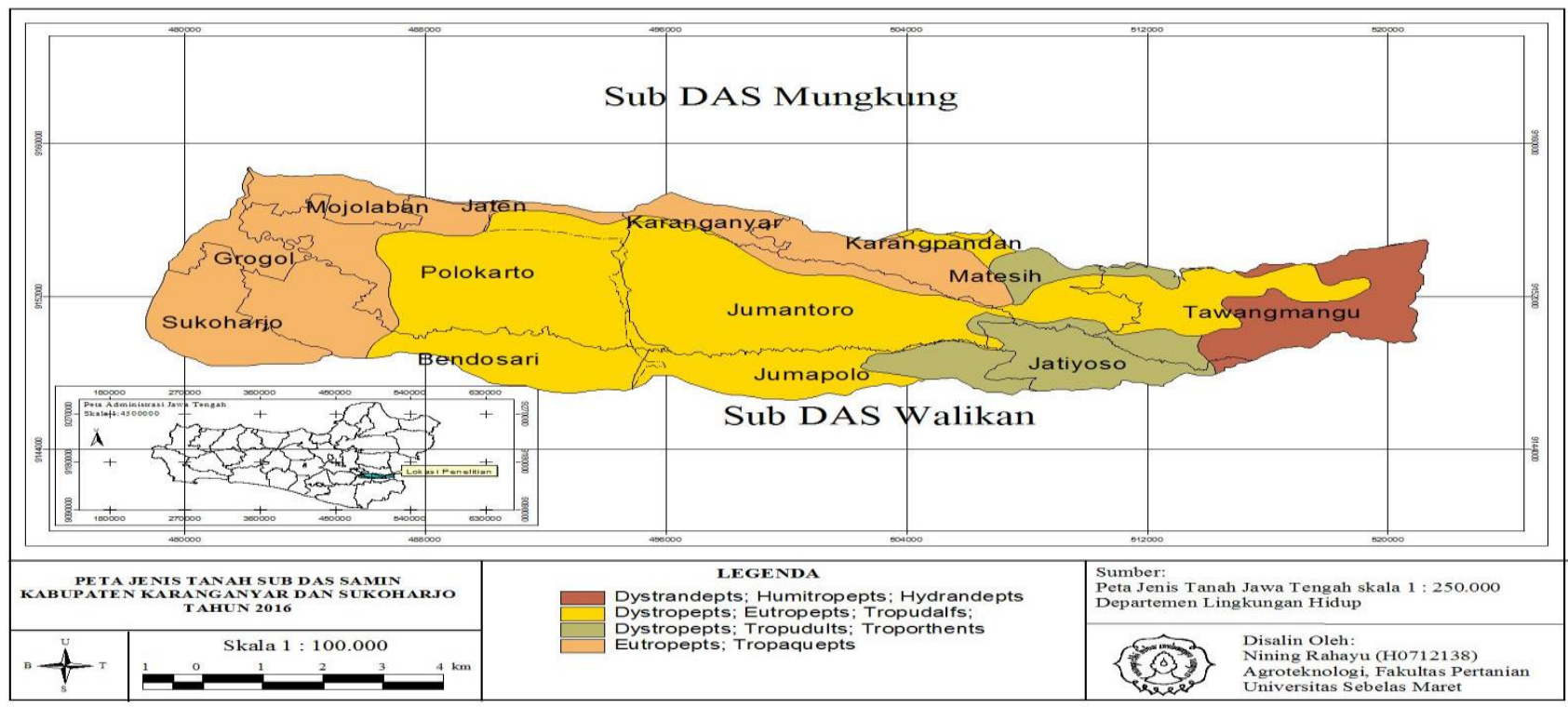

Gambar 2 Peta jenis tanah Sub DAS Samin bagian hulu (sebelah kanan) didominasi Dystrandepts dan bagian hilir (sebelah kiri) didominasi Eutropepts.

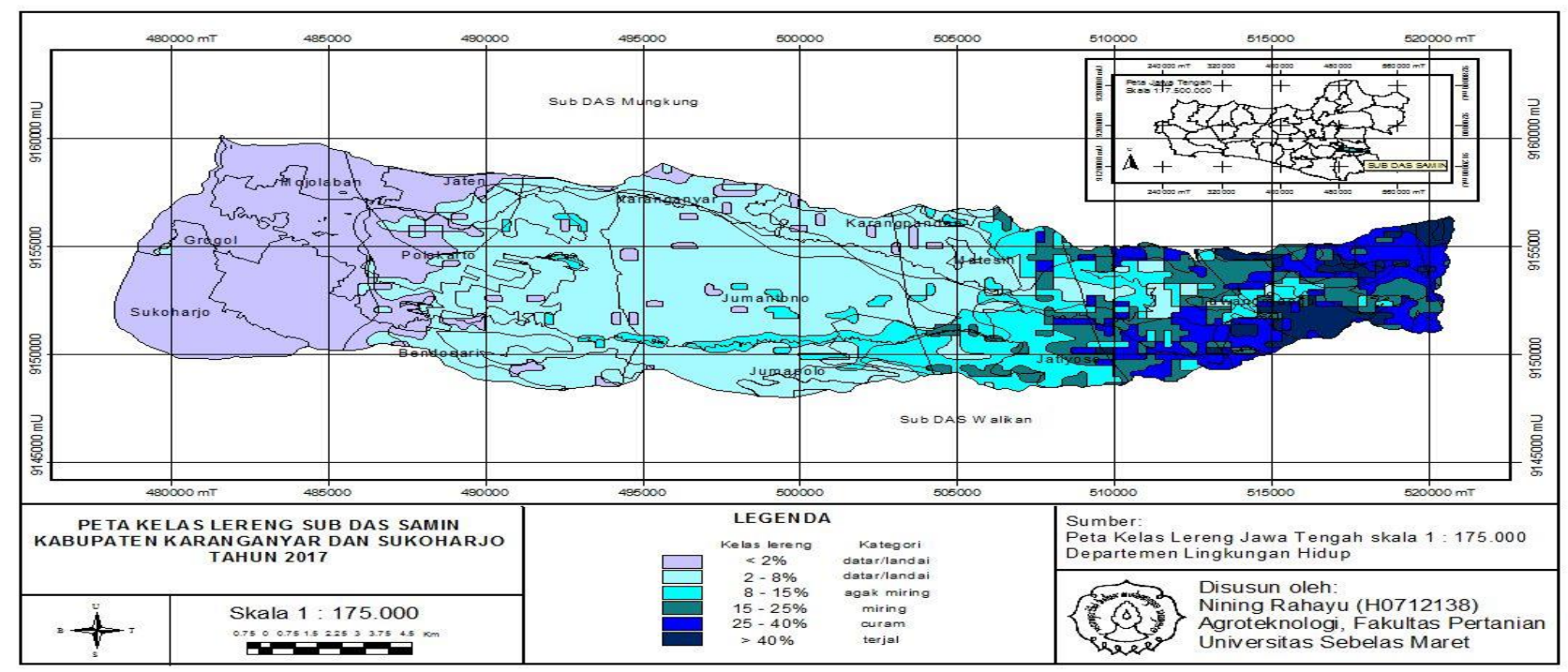

Gambar 3 Peta kelas lereng Sub DAS Samin bagian hulu (sebelah kanan) didominasi kelas lereng curam dan bagian hilir (sebelah kiri) didominasi kelas lereng landai.

Schmidt-Ferguson menetapkan tipe iklim untuk wilayah topis dengan rumus rata-rata bulan kering dibagi bulan basah (Irfan 2006). Sub DAS Samin bagian hulu memiliki nilai $Q=0,49$ dan bagian hilir memiliki nilai $Q=0,58$. Hal tersebut menunjukkan bagian hulu dan hilir Sub DAS Samin memiliki tipe iklim C (Agak basah). Tipe iklim Sub DAS Samin pada periode 2005-2010 dan 2010-2015 tidak mengalami perubahan. Pada tahun 2005-2010 Sub DAS Samin memiliki nilai $Q=0,5$ dan pada tahun 2010-2015 Sub DAS Samin memiliki nilai $Q=0,43$.

\section{Alih fungsi lahan}

Hasil perhitungan melalui program excel, informasi penggunaan lahan pada Tabel 1. menunjukkan lahan sawah mengalami penurunan sebesar 447,24 ha

dimana setiap tahun terjadi penurunan rata-rata sebesar 44,76 ha $^{-1}$ tahun. Lahan pemukiman mengalami peningkatan sebesar 267,97 ha, dimana setiap tahun terjadi peningkatan rata-rata sebesar $26,8 \mathrm{ha}^{-1}$ tahun. Lahan tegalan mengalami penurunan sebesar 662,19 ha, dimana setiap tahun terjadi penurunan rata-rata sebesar 54,07 ha tahun. Lahan hutan mengalami penurunan sebesar 918 ha atau setiap tahun terjadi penurunan sebesar 91,8 ha $^{-1}$ tahun. Lahan perkebunan mengalami penurunan sebesar 268,25 ha atau setiap tahun terjadi penurunan sebesar 26,82 ha $^{-1}$ tahun. Lahan lain-lain mengalami peningkatan sebesar $1.378,74$ ha yang berarti menunjukkan setiap tahun terjadi peningkatan sebesar $137,87 \mathrm{ha}^{-1}$ tahun. 
Tabel 1 Laju Penggunaan Lahan di Sub DAS Samin tahun 2005-2015

\begin{tabular}{lrrrrrrr}
\hline Tahun & \multicolumn{1}{c}{$\begin{array}{c}\text { Sawah } \\
\text { (ha) }\end{array}$} & $\begin{array}{c}\text { Pemukiman } \\
\text { (ha) }\end{array}$ & $\begin{array}{c}\text { Tegalan } \\
\text { (ha) }\end{array}$ & $\begin{array}{c}\text { Hutan } \\
\text { (ha) }\end{array}$ & $\begin{array}{c}\text { Perkebunan } \\
\text { (ha) }\end{array}$ & $\begin{array}{c}\text { Lain-lain } \\
\text { (ha) }\end{array}$ & Total Luas (ha) \\
\hline 2005 & $22.142,55$ & $17.869,99$ & $11.094,19$ & $5.303,34$ & 955,75 & $2.622,77$ & $59.988,59$ \\
2006 & $22.082,399$ & $18.039,86$ & $10.990,05$ & $5.303,34$ & 908,75 & $2.630,19$ & $59.988,59$ \\
2007 & $21.949,48$ & $18.189,63$ & $10.976,18$ & $5.303,34$ & 908,75 & $2.627,21$ & $59.988,59$ \\
2008 & $21.947,82$ & $18.204,26$ & $10.960,21$ & $5.303,34$ & 908,75 & $2.640,21$ & $59.988,59$ \\
2009 & $21.943,03$ & $18.222,26$ & 10.966 & $5.303,34$ & 908,75 & $9.895,47$ & $59.988,59$ \\
2010 & $21.941,16$ & $18.230,71$ & $10.904,92$ & $5.303,34$ & 908,75 & $2.649,21$ & $59.988,59$ \\
2011 & $21.293,7$ & $18.981,91$ & $10.784,15$ & $5.330,34$ & 928,2 & $2.624,89$ & $59.988,59$ \\
2012 & $21.827,31$ & $18.146,31$ & $10.972,38$ & $4.330,34$ & 928,22 & $3.624,89$ & $59.988,59$ \\
2013 & $21.752,31$ & $18.160,96$ & $10.799,76$ & 4.278 .34 & $1.079,22$ & $3.806,08$ & $59.988,59$ \\
2014 & $21.695,31$ & $18.137,96$ & 10.432 & 4.278 .34 & 1.224 & $3.929,81$ & $59.988,59$ \\
2015 & $21.695,31$ & $18.137,96$ & 10.432 & 4.278 .34 & 1.224 & $4.108,51$ & $59.988,59$ \\
\hline
\end{tabular}

Sumber:Hasil perhitungan data penggunaan lahan dari BPS Kabupaten Karanganyar dan Sukoharjo.

\section{Curah hujan}

Perhitungan curah hujan dilakukan dengan cara metode poligon Thiessen. Metode poligon Thiessen merupakan metode pengukuran curah hujan berdasarkan pembagian wilayah poligon dengan perpotongan garis yang membentuk sudut siku-siku. Beradasarkan hasil analisis melalui program software ArcView, pembagian wilayah Sub DAS Samin berdasarkan metode poligon Thiessen dapat dilihat pada Gambar 4.

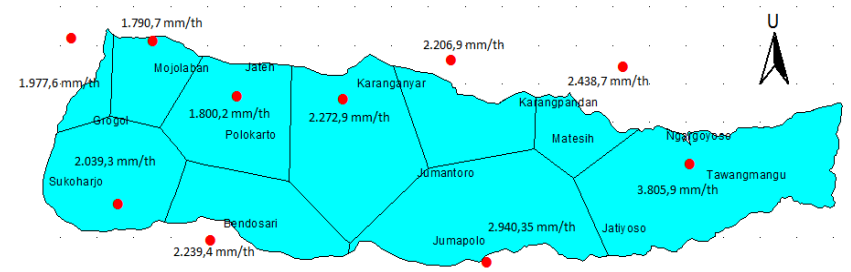

Gambar 4 Pembagian wilayah curah hujan sub DAS Samin berdasarkan metode poligon Thiessen.

Nilai curah hujan hasil perhitungan dari metode poligon Thiessen dapat dilihat pada Tabel 2. Curah hujan diukur dengan menggunakan alat Automatic Water Level Recorder (AWLR). Curah hujan dicatat setiap bulan dalam kurun waktu 2005-2015.

Tabel 2 Curah hujan sub DAS Samin (2005-2015)

\begin{tabular}{lrl}
\hline Tahun & $\begin{array}{l}\text { Curah Hujan } \\
\text { (mm/tahun) }\end{array}$ & Kategori Nilai \\
\hline 2005 & $2.325,48$ & Sedang \\
2006 & $1.994,29$ & Rendah \\
2007 & $2.549,07$ & Tinggi \\
2008 & $2.424,51$ & Sedang \\
2009 & $2.338,11$ & Sedang \\
2010 & $3.903,41$ & Sangat Tinggi \\
2011 & $2.229,79$ & Sedang \\
2012 & $2.379,75$ & Sedang \\
2013 & $2.463,80$ & Sedang \\
2014 & $2.201,72$ & Sedang \\
2015 & $2.342,92$ & Sedang \\
\hline
\end{tabular}

Sumber: Hasil analisis berdasarkan metode poligon Thiessen.

Curah hujan dari tahun 2005 sampai tahun 2015 di wilayah Sub DAS Samin berkisar $2.468 \mathrm{~mm} /$ tahun. Pada bagian hulu Sub DAS Samin (kawasan Gunung
Lawu) memiliki rata-rata curah hujan berkisar 2.700 $\mathrm{mm} /$ tahun, sedang bagian hilir (wilayah Kabupaten Sukoharjo) memiliki rata-rata curah hujan berkisar $1.800 \mathrm{~mm} /$ tahun.

\section{Keadaan hidrologi sub DASSamin}

Menurut Menteri Kehutanan (2009), evaluasi kinerja tata air DAS dapat dilakukan dengan mengetahui nilai bobot dan skor dari parameter kondisi hidrologi DAS. Parameter kondisi hidrologi DAS meliputi KRS, CV debit, $C$, Sedimentasi, Indeks Penggunaan Air (IPA) dan kandungan pencemar yang terdiri dari komponen fisika, kimia dan biologi.

Debit adalah volume aliran yang terjadi di suatu sungai pada periode waktu tertentu. Pada suatu sungai, nilai tinggi muka air dapat digunakan sebagai patokan dalam menduga besarnya debit yang terjadi. Debit sungai semakin besar jika tinggi muka air juga semakin besar (Sularto 2006). Data debit tahunan Sub DAS Samin dapat dilihat pada Tabel 3. Sub DAS Samin memiliki rata-rata debit sebesar $8.001,25 \mathrm{~m}^{3} /$ tahun. Debit tahunan Sub DAS Samin cenderung mengalami penurunan setiap tahunnya. Pada tahun 2005 sebesar $11.442,2 \mathrm{~m}^{3} /$ tahun menjadi $5.914,4 \mathrm{~m}^{3} /$ tahun pada tahun 2015.

Koefisien Regim Sungai (KRS) adalah bilangan yang menunjukkan perbandingan antara nilai debit maksimum $\left(Q_{\text {maks }}\right)$ dengan nilai debit minimum $\left(Q_{\min }\right)$ pada suatu Sub DAS. Nilai KRS tinggi menunjukkan kisaran nilai limpasan pada musim penghujan (air banjir) yang terjadi besar, sedang pada musim kemarau aliran air sangat kecil atau menunjukkan kekeringan (Departemen Kehutanan 2009). Nilai KRS Sub DAS Samin dapat dilihat pada Tabel 3. Tahun 2005 nilai KRS Sub DAS Samin dalam kondisi baik dan menjadi buruk saat tahun 2008. Nilai KRS tertinggi selama periode 10 tahun berada pada tahun 2011 sebesar 163,88. Pada tahun 2011 fluktuasi antara debit maksimum dengan debit minimum paling tinggi. Nilai KRS yang buruk menunjukkan bahwa pada musim penghujan dapat terjadi banjir dan pada musim kemarau aliran air sangat kecil atau menunjukkan gejala kekeringan (Retnowati 2012). Pada kondisi sekarang daya serap lahan di Sub DAS Samin kurang mampu menahan dan menyimpan air hujan yang masuk sehingga air limpasannya banyak yang mengalir 
langsung menuju sungai menyebabkan ketersediaan air menjadi sedikit.

Koefisien limpasan (C) merupakan nilai perbandingan (nisbah) antara besarnya limpasan terhadap penyebabnya yaitu curah hujan. Nilai Koefisien limpasan berkisar $0<\mathrm{C}<1$, yang artinya jika nilai $C=0,2$ menunjukkan $20 \%$ dari curah hujan menjadi limpasan (Departemen Kehutanan 2009). Pada Tabel 3. limpasan terbesar terjadi pada tahun 2005 sehingga didapat nilai $\mathrm{C}$ yang buruk sebesar 0,47 . Nilai C mulai membaik pada tahun 2010 dan 2012 yaitu sebesar 0,24 dan 0,23.

Koefisien variansi $\left(\mathrm{CV}_{\text {debit }}\right)$ merupakan gambaran kondisi variasi dari debit aliran air (Q) tahunan dari suatu DAS. Nilai variasi debit tahunan $\left(\mathrm{CV}_{\text {debit }}\right)$ menunjukkan indikator kontinuitas air suatu DAS. Jika kondisi variasi debit tahunan kecil maka kondisi debit (Q) dari tahun ke tahun tidak banyak mengalami perubahan. Kondisi variasi debit tahunan besar menunjukkan kondisi DAS kurang stabil (Departemen
Kehutanan 2009). Nilai $\mathrm{CV}_{\text {debit }}$ sudah lebih besar dari 0,3 sejak tahun 2005, hal tersebut menunjukkan bahwa Sub DAS Samin mengalami ketidakstabilan aliran. Nilai $\mathrm{CV}_{\text {debit }}$ periode 2005-2015 selalu buruk dengan nilai $\mathrm{CV}_{\text {debit }}$ yang cenderung meningkat setiap tahunnya.

Sedimentasi adalah jumlah material tanah dalam air oleh aliran sungai dari hasil proses erosi di hulu kemudian diendapkan di daerah hilir dimana kecepatan pengendapan butir-butir material suspensi telah lebih kecil dari kecepatan angkutannya (Departemen Kehutanan 2009). Sedimen dapat memblokir saluran air dan menyebabkan bahaya banjir. Topografi, iklim, penggunaan lahan, tutupan lahan dan lain-lain merupakan faktor yang mempengaruhi produksi dan transportasi sedimen dalam wilayah DAS (Alemu 2016). Nilai sedimentasi Sub DAS Samin dapat dilihat pada Tabel 3. Nilai sedimentasi tertinggi terjadi pada tahun 2005 sebesar 0,02 $\mathrm{mm}$ dan nilai sedimentasi terendah terjadi pada tahun 2012 sebesar 0,01 mm.

Tabel 3 Kondisi Hidrologi Sub DAS Samin tahun 2005-2015

\begin{tabular}{|c|c|c|c|c|c|c|c|c|c|}
\hline \multirow[t]{2}{*}{ Tahun } & \multirow{2}{*}{$\begin{array}{c}\text { Debit } \\
\left(\mathrm{m}^{3} / \mathrm{th}\right)\end{array}$} & \multicolumn{2}{|c|}{ KRS } & \multicolumn{2}{|c|}{$\mathrm{CV}_{\text {debit }}$} & \multicolumn{2}{|c|}{$\mathrm{C}$} & \multicolumn{2}{|c|}{ Sedimentasi } \\
\hline & & Nilai & Harkat & Nilai & Harkat & Nilai & Harkat & Nilai & Harkat \\
\hline 2005 & 11442,2 & 9,84 & Baik & 0,56 & Buruk & 0,50 & Buruk & 0,02 & Baik \\
\hline 2006 & 8812,6 & 18,28 & Baik & 0,75 & Buruk & 0,47 & Buruk & 0,01 & Baik \\
\hline 2007 & 9655,6 & 44,26 & Baik & 0,77 & Buruk & 0,43 & Buruk & 0,02 & Baik \\
\hline 2008 & 9357,8 & 149,65 & Buruk & 0,69 & Buruk & 0,45 & Buruk & 0,02 & Baik \\
\hline 2009 & 5890 & 99,36 & Sedang & 1,01 & Buruk & 0,27 & sedang & 0,01 & Baik \\
\hline 2010 & 10330,2 & 43,61 & Baik & 0,55 & Buruk & 0,24 & Baik & 0,02 & Baik \\
\hline 2011 & 7090,2 & 163,88 & Buruk & 0,90 & Buruk & 0,34 & sedang & 0,01 & Baik \\
\hline 2012 & 5346,1 & 146,03 & Buruk & 1,14 & Buruk & 0,23 & Baik & 0,01 & Baik \\
\hline 2013 & 6173,4 & 137,31 & Buruk & 1,04 & Buruk & 0,28 & sedang & 0,01 & Baik \\
\hline 2014 & - & . & - & - & - & - & - & - & - \\
\hline 2015 & 5914,4 & 160,19 & Buruk & 1,20 & Buruk & 0,26 & sedang & 0,01 & Baik \\
\hline
\end{tabular}

Sumber: Hasil Analisis dari data hidrologi BPTKP DAS Solo

Keterangan: - = data tidak ada.

\section{Perubahan kondisi hidrologi sub DAS Samin}

Keadaan kondisi hidrologi Sub DAS Samin jika dilihat secara dua periode antara tahun 2005-2010 dan 2011-2015 dapat dilihat pada Tabel 4. Pada tabel tersebut terlihat bahwa Sub DAS Samin mengalami penurunan rata-rata debit tahunan dari 9.248,07 $\mathrm{m}^{3}$ /detik menjadi $6.130,65 \mathrm{~m}^{3} /$ detik (menurun sebesar $3.117,42 \mathrm{~m}^{3} /$ detik). Nilai KRS secara nilai dan harkat termasuk memburuk yaitu dari 60,83 menjadi 151,85 (meningkat sebesar 91,02). Nilai $\mathrm{CV}_{\text {debit }}$ secara harkat tetap jelek tetapi secara angka meningkat dari 0,72 menjadi 1,07 (meningkat sebesar 0,35). Nilai koefisien limpasan (C) secara harkat tetap termasuk kategori sedang tetapi secara angka termasuk menurun yaitu dari 0,39 menjadi 0,28 (menurun sebesar 0,11). Sedimentasi masih dalam kondisi baik tetapi secara angka menurun sebesar 0,01 $\mathrm{mm}$.

Tabel 4 Perubahan kondisi hidrologi sub DAS Samin tahun 2005-2010 dan 2010-2015

\begin{tabular}{lrrlrlllrl}
\hline \multirow{2}{*}{ Periode } & \multicolumn{7}{c}{ Rata-Rata Kondisi Hidrologi } \\
\cline { 2 - 9 } & Debit & KRS & Harkat & \multicolumn{1}{c}{ CV debit } & Harkat & C & Harkat & Sedimentasi & Harkat \\
\hline $2005-2010$ & $9.248,07$ & 60,83 & Sedang & 0,72 & Jelek & 0,39 & Sedang & 0,02 & baik \\
$2010-2015$ & $6.130,65$ & 151,85 & jelek & 1,07 & Jelek & 0,28 & Sedang & 0,01 & baik \\
\hline selisih & $-3.117,42$ & $+91,02$ & & $+0,35$ & & $-0,11$ & & $-0,01$ & \\
\hline
\end{tabular}

Sumber: Hasil analisis.

\section{Hasil korelasi}

Penelitian Homdee et al. (2011) mengenai model simulasi perubahan penggunaan lahan menunjukkan perubahan penggunaan lahan yang berbeda mempengaruhi perbedaan hasil debit air dan evapotranspirasi. Hal tersebut disebabkan oleh perbedaan jenis tanaman dan pola tanam. Penelitian
Coe et al. (2009), pada skala mikro sampai skala-meso, deforestasi hutan umumnya menghasilkan penurunan evapotranspirasi dan peningkatan limpasan, dan debit. Pada skala besar, pengaruh atmosfer secara signifikan dapat mengurangi curah hujan regional dan jika kondisinya lebih besar dari perubahan evapotranspirasi lokal, dapat menurunkan hasil air, limpasan dan debit. Pada penelitian Du et al. (2012) menunjukkan bahwa 
potensi perubahan debit puncak dan volume banjir memiliki hubungan linear terhadap peningkatan lahan permukaan kedap air dan perubahan limpasan di tahun kering lebih besar dibanding tahun basah. Ketersediaan sumberdaya air permukaan saat musim kemarau lebih sensitif terhadap urbanisasi dibanding saat musim hujan.

Hasil korelasi alih fungsi lahan terhadap perubahan kondisi hidrologi Sub DAS Samin dapat dilihat pada Tabel 5. Laju penurunan lahan sawah sangat signifikan berkorelasi negatif terhadap peningkatan nilai KRS. Laju penurunan lahan tegalan secara signifikan berkorelasi positif terhadap peningkatan nilai KRS dan peningkatan $\mathrm{CV}_{\text {debit. }}$ Laju peningkatan lahan kebun secara signifikan berkorelasi positif terhadap peningkatan nilai $\mathrm{CV}_{\text {debit. }}$ Laju penurunan lahan hutan secara signifikan berkorelasi positif terhadap penurunan nilai debit tahunan, penurunan nilai $\mathrm{C}$ dan penurunan sedimentasi, tetapi secara signifikan berkorelasi negatif terhadap peningkatan nilai KRS dan secara sangat signifikan berkorelasi negatif terhadap peningkatan $\mathrm{CV}_{\text {debit. }}$ Laju peningkatan lahan lain-lain secara signifikan berkorelasi negatif terhadap penurunan debit tahunan, penurunan nilai $\mathrm{C}$ tetapi secara sangat signifikan berkorelasi positif terhadap peningkatan nilai $\mathrm{CV}_{\text {debit. }}$

Perubahan tutupan lahan hijau menjadi pemukiman akan mengakibatkan perubahan siklus hidrologi setempat. Hal tersebut karena peningkatan luasan tutupan lahan kedap air akan menyebabkan peningkatan volume aliran permukaan dan mengurangi jumlah infiltrasi (Sudarto 2009). Penelitian yang dilakukan Rauf (2014) menunjukkan bahwa peningkatan pemukiman sebesar 6,99\% (2003-2008) dan 3,91\% (2008-2013) menyebabkan peningkatan koefisien limpasan sebesar 0,48 (2003), 0,53 (2008) dan 0,56 (2013). Peningkatan lahan terbangun sebesar 149\% pada Sub DAS Cikapundung Gandok (Bandung) dapat meningkatkan koefisien limpasan sebesar $0.51 \%$, meningkatkan debit maksimum harian dan menurunkan debit minimum harian (Wibowo 2005).

Penelitian yang telah dilaksanakan Retnowati (2012) menunjukkan pada tahun 1997 hingga tahun 2007 di DAS Ngunut I telah terjadi penurunan penggunaan lahan sawah sebesar 155,6 ha menjadi 48,46 ha dan penurunan lahan tegalan sebesar 288,50 ha menjadi 148,80 ha mempengaruhi penurunan sedimen dari 26,88 mm/tahun menjadi 0,26 mm/tahun. Pada SubSub DAS Tapan penurunan lahan sawah sebesar 10,59 ha menjadi 10 ha dan penurunan lahan tegalan sebesar 115,46 ha menjadi 56 ha akan menyebabkan penurunan sedimentasi dari $36,15 \mathrm{~mm} /$ tahun menjadi $0,58 \mathrm{~mm} /$ tahun.

Karakteristik banjir yang terjadi pada suatu wilayah DAS dipengaruhi oleh karakteristik hujan (tebal, durasi dan intensitas hujan) dan kondisi awal lengas tanah. Karakteristik hujan lebih mempengaruhi debit puncak dan kondisi awal lengas tanah lebih memengaruhi waktu untuk menuju debit puncak (Purwanto ${ }^{a}$ et al., 2013). Debit sungai cenderung mengikuti dinamika curah hujan, hal ini terlihat dari penelitian di DAS Mamasa (Sulawesi Barat), debit tertinggi terjadi pada periode 1991-1999 dimana terjadi curah hujan tinggi dan debit terendah pada periode 2000-2005 dimana terjadi curah hujan terendah. Lama waktu hujan, intensitas dan penyebaran hujan mempengaruhi laju dan volume debit sungai (Muchtar dan Abdullah 2012).

Tabel 5 Hasil analisis korelasi curah hujan dan alih fungsi lahan terhadap kondisi hidrologi sub DAS Samin

\begin{tabular}{|c|c|c|c|c|c|c|}
\hline Variabel & & Debit & KRS & $\mathrm{CV}_{\text {debit }}$ & $\mathrm{C}$ & Sedimentasi \\
\hline \multirow[t]{2}{*}{ Hujan } & Pearson Correlation & .329 & -.200 & -.411 & .263 & .300 \\
\hline & Sig. (1-tailed) & .176 & .290 & .119 & .231 & .200 \\
\hline \multirow[t]{2}{*}{ Pemukiman } & Pearson Correlation & -.287 & .524 & .166 & -.264 & -.307 \\
\hline & Sig. (1-tailed) & .211 & .060 & .324 & .231 & .194 \\
\hline \multirow[t]{2}{*}{ Sawah } & Pearson Correlation & .549 & -.750 & -.502 & .513 & .529 \\
\hline & Sig. (1-tailed) & .050 & $.006^{\star \star}$ & .070 & .065 & .058 \\
\hline \multirow[t]{2}{*}{ Tegalan } & Pearson Correlation & .525 & -.609 & -.614 & .509 & .478 \\
\hline & Sig. (1-tailed) & .059 & $.031^{\star}$ & $.030^{\star}$ & .067 & .081 \\
\hline \multirow[t]{2}{*}{ Kebun } & Pearson Correlation & -.428 & .424 & .586 & -.397 & -.354 \\
\hline & Sig. (1-tailed) & .108 & .111 & $.038^{*}$ & .127 & .158 \\
\hline \multirow[t]{2}{*}{ Hutan } & Pearson Correlation & .743 & -.756 & -.774 & .697 & .681 \\
\hline & Sig. (1-tailed) & $0.007^{\star \star}$ & $.006^{*}$ & $.004^{\star}$ & $.013^{\star}$ & $.015^{\star}$ \\
\hline \multirow[t]{2}{*}{ Lain-lain } & Pearson Correlation & -.587 & .744 & .806 & -.710 & -.683 \\
\hline & Sig. (1-tailed) & $.037^{\star}$ & $.007^{\star \star}$ & $.002^{\star \star}$ & $.011^{\star}$ & $.015^{\star}$ \\
\hline
\end{tabular}

Sumber: Hasil Analisis korelasi melalui program SPSS.

Hasil analisis korelasi nilai hujan hasil perhitungan metode poligon Thiessen terhadap perubahan kondisi hidrologi Sub DAS Samin dapat dilihat pada Tabel 5. Faktor hujan belum mempengaruhi perubahan kondisi hidrologi yang berada di Sub DAS Samin. Hal tersebut tidak sejalan dengan penelitian yang telah dilaksanakan oleh Aamery et al. (2016) menunjukkan debit sungai cenderung mengikuti perubahan curah hujan dan mengalami peningkatan sebesar $10 \%$ untuk DAS beriklim basah dan $11 \%$ untuk DAS beriklim sedang.
Penelitian Ma et al. (2009) yang menyatakan bahwa variasi musiman debit sungai dipengaruhi oleh variasi musiman curah hujan dan aliran permukaan air lebih sensitif terhadap perubahan penggunaan lahan. Sebenarnya faktor hujan dapat mempengaruhi kondisi hidrologi Sub DAS sebagaimana yang disampaikan oleh Muchtar dan Abdullah (2012) lama waktu hujan, intensitas dan penyebaran hujan mempengaruhi laju dan volume debit sungai. Beberapa kemungkinan penyebab faktor curah hujan belum mempengaruhi 
kondisi hidrologi Sub DAS Samin antara lain; pada penelitian ini analisis faktor nilai hujan belum mempengaruhi perubahan kondisi hidrologi Sub DAS Samin dikarenakan penentuan titik sampel hujan belum mewakili keadaan yang sebenarnya. Hal tersebut dikarenakan minimnya data curah hujan di bagian hulu Sub DAS Samin menyebabkan analisis curah hujan melalui metode poligon Thiessen menjadi kurang memadai.

Kemungkinan lain, terjadi banyaknya hujan lokal dan pemanfaatan air permukaan secara langung yang belum terdeteksi. Penelitian yang telah dilakukan oleh Supangat dan Sukresno (2009), fluktuasi debit yang terjadi di sungai Bengawan Solo banyak dipengaruhi fenomena lokal seperti hujan lokal, pemanfaatan air di wilayah-wilayah tertentu seperti untuk irigasi maupun industri. DAS Solo memiliki wilayah luas sehingga curah hujan yang terjadi tidak merata membuat kontribusi hujan lokal di tempat lain tidak terdeteksi menjadi penentu besarnya debit aliran di SPAS tertentu. Penelitian Jayasree dan Venkatesh (2012) sejak DAS Dasanakatte semenjak terjadi peningkatan lahan pertanian dan perkebunan, pola debit aliran cenderung menurun terutama saat musim kemarau akibat penggunaan air untuk lahan tersebut.

Korelasi hujan menggunakan data curah hujan masing-masing stasiun pengukur hujan yang terdapat di wilayah Sub DAS Samin dapat dilihat pada Tabel 6. Curah hujan di wilayah Karangpandan dan Jumapolo mempengaruhi perubahan kondisi hidrologi Sub DAS Samin. Curah hujan di wilayah Karangpandan mempengaruhi penurunan debit tahunan, debit ratarata, $\mathrm{CV}_{\text {debit}}$, limpasan, koefisien limpasan $(\mathrm{C})$, debit suspensi dan sedimentasi. Curah hujan di wilayah Jumapolo hanya mempengaruhi penurunan nilai $\mathrm{CV}_{\text {debit}}$.

Tabel 6 Nilai korelasi hujan terhadap perubahan kondisi hidrologi Sub DAS Samin

\begin{tabular}{|c|c|c|c|c|c|c|}
\hline Hujan & & Debit & KRS & $\mathrm{CV}_{\text {debit }}$ & $\mathrm{C}$ & Sedimentasi \\
\hline \multirow{2}{*}{ Poligon } & Pearson Correlation & .329 & -.200 & -.411 & .263 & .300 \\
\hline & Sig. (1-tailed) & .176 & .290 & .119 & .231 & .200 \\
\hline \multirow{2}{*}{ Sukoharjo } & Pearson Correlation & .198 & -.202 & -.355 & .149 & .139 \\
\hline & Sig. (1-tailed) & .292 & .288 & .157 & .341 & .351 \\
\hline \multirow{2}{*}{ Grogol } & Pearson Correlation & .077 & -.074 & -.166 & .084 & .067 \\
\hline & Sig. (1-tailed) & .417 & .420 & .323 & .409 & .427 \\
\hline \multirow{2}{*}{ Mojolaban } & Pearson Correlation & .252 & -.001 & -.178 & .158 & .249 \\
\hline & Sig. (1-tailed) & .242 & .499 & .312 & .332 & .244 \\
\hline \multirow{2}{*}{ Polokarto } & Pearson Correlation & .528 & -.482 & -.482 & .466 & .506 \\
\hline & Sig. (1-tailed) & .058 & .079 & .079 & .087 & .068 \\
\hline \multirow{2}{*}{ Bendosari } & Pearson Correlation & .100 & -.101 & -.186 & .048 & .054 \\
\hline & Sig. (1-tailed) & .391 & .391 & .304 & .448 & .441 \\
\hline \multirow{2}{*}{ Jumantono } & Pearson Correlation & .232 & -.022 & -.281 & .185 & .204 \\
\hline & Sig. (1-tailed) & .259 & .476 & .216 & .305 & .286 \\
\hline \multirow{2}{*}{ Karanganyar } & Pearson Correlation & .354 & -.212 & -.376 & .281 & .316 \\
\hline & Sig. (1-tailed) & .158 & .279 & .142 & .216 & .187 \\
\hline \multirow{2}{*}{ Karangpandan } & Pearson Correlation & .613 & -.393 & -.633 & .565 & .603 \\
\hline & Sig. (1-tailed) & $.030^{\star}$ & .130 & $.025^{\star}$ & $.045^{\star}$ & $.032^{*}$ \\
\hline \multirow{2}{*}{ Jumapolo } & Pearson Correlation & -.577 & .341 & .666 & -.565 & -.531 \\
\hline & Sig. (1-tailed) & .052 & .184 & $.025^{\star}$ & .057 & .070 \\
\hline \multirow{2}{*}{ Tawangmangu } & Pearson Correlation & .369 & .004 & -.379 & .231 & .330 \\
\hline & Sig. (1-tailed) & .147 & .495 & .140 & .260 & .176 \\
\hline
\end{tabular}

Sumber: Hasil analisis.

\section{KESIMPULAN DAN SARAN}

\section{Kesimpulan}

Kesimpulan dari penelitian ini adalah sebagai berikut:

1. Lahan sawah dan hutan mengalami penurunan ratarata masing-masing sebesar $44,76 \mathrm{ha}^{-1}$ th dan 102,5 ha $^{-1}$ th. Lahan pemukiman, tegalan dan perkebunan mengalami peningkatan rata-rata masing-masing sebesar 26,8 ha $^{-1}$ th, 54,07 ha $^{-1}$ th dan 26,82 ha 1 tahun.

2. Pada periode $2005-2010$ dan 2011-2015, Sub DAS Samin mengalami penurunan rata-rata debit tahunan $\left(-3.117,42 \mathrm{~m}^{3} /\right.$ detik $)$, nilai koefisien limpasan $(-0,11)$, debit suspensi $\left(-23,5 \mathrm{~kg}^{-1}\right.$ detik), sedimentasi $(-0,01 \mathrm{~mm})$ dan peningkatan rata-rata nilai Koefisien Regim Sungai $(+91,02)$ dan $C_{\text {debit }}$ $(+0,35)$.

3. Penurunan lahan sawah, hutan dan peningkatan lahan tegalan mempengaruhi peningkatan nilai Koefisien Regim Sungai (KRS). Penurunan lahan hutan dan peningkatan lahan tegalan serta perkebunan mempengaruhi peningkatan nilai Coefficient of Variants $\left(\mathrm{CV}_{\text {debit }}\right)$. Penurunan lahan hutan mempengaruhi penurunan nilai koefisien limpasan (C), sedimentasi dan debit tahunan.

\section{Saran}

Sebaiknya data curah hujan sekunder menggunakan data curah hujan harian untuk mengantisipasi data curah hujan bulanan yang tidak normal karena data curah hujan harian yang bolong (tidak ada data). 


\section{DAFTAR PUSTAKA}

Aamery NA, Fox JF, Synder M. 2016. Evaluation of climate modeling factors impacting the variance of streamflow. J Hydrol. 542:125-142.

Alemu MM. 2016. Integrated watershed management and sedimentation. J Environ Protect. 7:490-494.

Anna AN, Kaeksi RW, Astuti WA. 2010. Analisis karakteristik parameter hidrologi akibat alih fungsi lahan di daerah Sukoharjo melalui citra landsat tahun 1997 dengan tahun 2002. J Forum Geografi. 24(1):57-72.

Asdak C. 2007. Hidrologi dan pengelolaan daerah aliran sungai. Yogyakarta: Gajah Mada Universitiy Press.

Coe MT, Costa MH, Filho BS. 2009. The influence of historical and potential future deforestation on the stream flow of the amazon river-land surface processes and atmospheric feedbacks. J Hydrol. 369:165-174.

Departemen Kehutanan. 2009. Peraturan Direktur Jenderal Rehabilitasi Lahan dan Perhutanan Sosial: Pedoman monitoring dan evaluasi daerah aliran sungai. Nomor: p.04/v-set/2009.

Du J, Qian L, Rui H, Zuo T, Zheng D, Xu Y, Xu CY. 2012. Assesing the effects of urbanization on annual runoff and flood events using an integrated hydrological modeling system for qinhuai river basin, china. J Hydrol 464-465:127-139. DOI:10.1016/j.hydrol.2012.06.057

Homdee T, Pongput K, Kanae S. 2011. Impacts of land cover changes on hydrologic responses: a case study of chi river basin, thailand. AJ Hydraulic Eng 55:31-36.

Irfan M. 2006. The determination of Palembang climate type by using Schmidt-Ferguson method. This paper published in The $2^{\text {nd }}$ Joint International Conference on "Sustainable Energy and Environment (SEE) 2006". P1-2.

Jayasree V, Vankatesh B. 2012. Evaluating the hydrological response to land cover changedasanakatte catchment of varahi river, western ghats, karnataka. IJWREM 3(1):23-32.

Ma X, Xu J, Luo Y, Aggarwal SP, Li J. 2009. Response of hydrological processes to land-cover and climate changes in kejie watershed, south-west china. J Hydrol Process (2009). DOI:10.1002/hyp.7233.

Mardini A, Susanti PD. 2016. Analysis physical characteristics of land for estimated runoff coefficient as flood control effort in comal watershed, central java. J Forum Geografi. 30(1):58-68.

Marganingrum D, Arwin, Roosmini D dan Pradono. 2013. Dampak variabilitas hujan dan konversi lahan terhadap sensitifitas debit aliran sungai citarum. J Forum Geografi. 27(1):11-22.

Muchtar A, Abdullah N. 2012. Analisis faktor-faktor yang mempengaruhi debit sungai mamasa. J Hut Mas. 2(1):174-187.

Price K. 2011. Effects of watershed topography, soils, land use, and climate on baseflow hydrology in humid regions: A review. 35(4):465-492.

Purwanto $^{a}$, Pujinugroho N, Nugroho AW. 2013. 12 Juni 2013: Surakarta. Disampaikan dalam Seminar Nasional Hasil Penelitian Teknologi Pengelolaan DAS oleh Balai Penelitian Teknologi Kehutanan Pengelolaan DAS, Kementerian Kehutanan, 12 juni 2013.

Rauf A. 2014. Pengaruh perubahan tata guna lahan terhadap koefisien limpasan (run off) kota makassar berbasis sig. Tugas akhir. Universitas Hasanuddin. Makassar.

Retnowati S. 2012. Dampak alih fungsi lahan terhadap kondisi tata air di sub-sub das ngunut I dan sub-sub das tapan (sub das samin). Tesis. Universitas Sebelas Maret. Surakarta.

Sharma SB, Singh AK. 2014. Assessment of the flood potential on a lower tapi basin tributary using scs-cn method integrated with remote sensing \& gis data. $J$ Geogr Nat Disast. 4(2):1-7.

Sudarto. 2009. Analisis pengaruh perubahan tata guna lahan terhadap peningkatan jumlah aliran permukaan (studi kasus pada das kali gatak di surakarta, jawa tengah). Tesis. Universitas Sebelas Maret. Surakarta.

Sudaryanto R. 2010. Analisis penggunaan lahan pertanian di kawasan lindung das samin untuk mitigasi bencana longsor dan banjir. J Sains Tan. $7(1): 41-49$.

Sularto E. 2006. Hubungan penggunaan lahan dan kejadian banjir pada das ciliwung hulu, katulampa menggunakan model answers. Skripsi. IPB. Bogor.

Supangat AB dan Sukresno. 2009. Studi penelusuran perjalanan air banjir di sungai bengawan solo. J Info Hutan. 6(2):185-198.

Suyana J. 2003. Analisis keberlanjutan biofisik lahan pada beberapa tipe agroekosistem di sub das samin, das bengawan solo. J Sains Tan. 3(1):1-12.

Wibowo M. 2005. Analisis pengaruh perubahan penggunaan lahan terhadap debit sungai. J Teknik Ling. 6(1):283-290.

Winarno J, Ariyanto DP, Hartati S, Rosariastuti R. 2008. Kajian bahaya erosi pada lahan kering di sub das samin kabupaten karanganyar. J Sains Tan. 5(2):101-106. 